\title{
Changes in Society after Natural Disasters
}

\author{
Roslinawati \\ Department of Sociology, Tadulako University, Palu, Indonesia
}

\begin{abstract}
Natural disasters greatly affect people's lives, both in terms of behavior and socio-economic conditions. This study aimED to determine and analyze changes in the behavior and socio-economic conditions of the community after natural disasters in Palu City. This research was designed qualitatively with a descriptive approach. The population of this research was the people of Palu City. The research sample was determined purposively. The data collection technique was a direct observation in the field and in-depth interviews. The data analysis was carried out qualitatively, consisting of the data reduction stage, data presentation, and conclusion drawing. The results of the study found that there had been a change in the behavior and socio-economic conditions of the people of Palu City after the earthquake disaster on September 28, 2018. Changes in behavior were indicated from mutual help and kinship between individuals in society which was higher after the disaster. Even the community seems to have family ties to each other even though they are not. Meanwhile, from the socioeconomic conditions, there have also been significant changes marked by changes in life in the post-disaster community. Many people have lost their property due to infrastructure damage and this has made the social and economic conditions of the community deteriorate. Damage to infrastructure has resulted in the loss of job opportunities, which then has an impact on decreasing community income after the disaster.
\end{abstract}

Keywords : disaster, community, change, behavior change, socioeconomy

\section{INTRODUCTION}

$\mathrm{G}$ eographically and ecologically, Indonesia has a high level of disaster threat (Hidayati, 2008; Pratikno, Rahmat, \& Sumantri, 2020; Prihatin, 2018; Rahmat \& Alawiyah, 2020; Utomo \& Minza, 2016) due to its location which is on the line ring of fire in the Pacific Ocean (Dewi \& Sukmawati, 2020) and is located at the confluence of active tectonic plates, active mountain ranges, and tropical climates (Mahdia \& Noviyanto, 2013).

The phenomenon of natural disasters has been common in recent years, which has become the world's attention (Siahaya, Siahaya, \& Rinukti, 2020). The occurrence of natural disasters certainly has a lot of negative impacts on people's lives, including the large number of casualties, loss of property, environmental damage, and disruption of the psychological function of victims of natural disasters (Utomo \& Minza, 2016). The number of casualties illustrates that community preparation and preparedness in facing disasters is still low, especially as a result of a lack of knowledge and concern for natural phenomena and the results of disasters (Hidayati, 2008).
One of the natural disasters that occurred in Indonesia was an earthquake in Palu City which resulted in a tsunami and liquefaction simultaneously on September 28, 2018. The disaster had a bad impact on people's lives and caused a deep sense of fear in the community. This condition in turn has an impact on changes in society, especially after a disaster. Various changes in society can easily be found, such as a higher sense of help, a stronger brotherhood, even without having to have any family relationships at all. The biggest change found was the change in the socio-economic conditions of the community after the disaster. This provides a lesson for the community, especially in the city of Palu, that the devastating disaster provided deep wisdom and meaning. This background encourages a study to be conducted with the aim of knowing and analyzing changes in behavior and socioeconomic conditions of the community after natural disasters in Palu City.

\section{METHOD}

This research was qualitative research designed descriptively, namely by describing the events that occurred after the natural disaster in Palu City on September 28, 2018. Qualitative research should find a deep meaning for phenomena and facts in the field. The population of this study were the people of Palu City who affected by the disaster in eight sub-districts (Mantikulore, West Palu, South Palu, East Palu, North Palu, Tatanga, Tawaeli, and Ulujadi). Sampling conducted using a purposive technique with a sample size of 2 (two) respondents in each sub-district so that 16 respondents is totally informants in the interview. The use of this technique was intended so that the research sample is determined deliberately with the consideration that the sample understand the problems and objectives of this study. Figure 1 shows the profile of the respondents or this research sample.

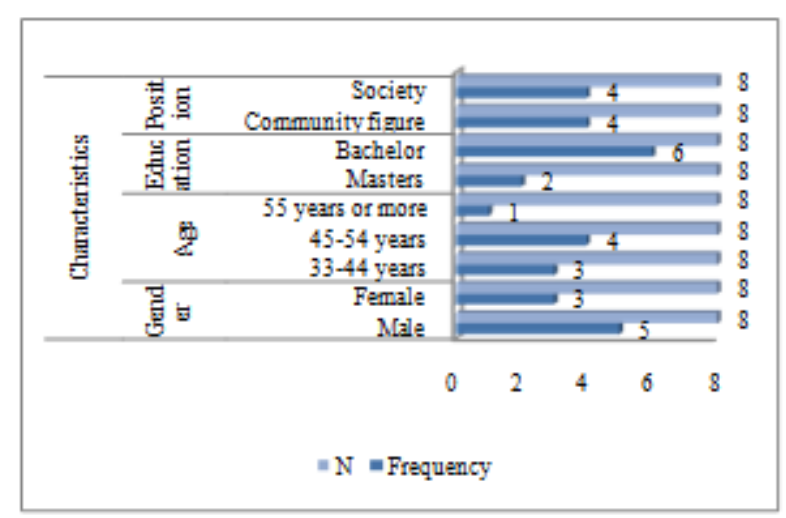

Figure 1. Participants' demographic profile 
The data collection was carried out through direct observation in the field followed by interviews with people who are considered affected by natural disasters in Palu City. The data collected through these two techniques were analyzed qualitatively and described in several stages starting from data reduction, data presentation, and drawing conclusions.

\section{FINDINGS AND DISCUSSION}

The intensity of natural disasters that are increasingly occurring in various parts of the world including Indonesia recently has resulted in many casualties, in addition to property losses (Siahaya et al., 2020). This situation caused deep trauma for the people who experienced it so that it affected their post-disaster situation. The various impacts caused by natural disasters, based on the results of research, show that there are significant changes in people's lives, especially in terms of behavior and socio-economic conditions.

\section{A. Change in Community Behavior}

Changes in people's behavior can be seen during and after the earthquake disaster that occurred on September 28, 2018. The occurrence of a natural disaster seemed to make the people of Palu City have to start everything from scratch. The impact of the earthquake which caused a lot of damage made people feel a sense of mutual help. This proves that there has been a change in people's behavior. Before the earthquake, the people of Palu City tended to not care about one another. This is reflected in the increasing life of the community, which causes less concern for one another. This changed after the earthquake hit Palu, where the community then had a high sense of mutual help even though they did not have family ties. The kinship among the people of Palu is getting closer with a high sense of brotherhood.

This post-disaster change in community behavior means that the attitude of help and kinship is very important so it needs to be maintained. Even though the people of Indonesia in general, and in particular the people of Palu City, have a sense of help and kinship, over time, this condition has eroded and causes the habits that show helping each other to decrease and even become visible. The mutual cooperation system itself has developed in Indonesia since the heyday of the Hindu Kingdom on the island of Java (Utomo \& Minza, 2016). The research findings found that the impact of the earthquake that occurred in Palu City regrew an attitude of help and kinship that had previously decreased and changes in community behavior that had previously begun to disappear, are now reestablished.

The results of this study generally mean that increasingly complex human life will result in changes in people's behavior and the erosion of old habits that tend to be positive by new ones. However, this will be different if a natural disaster occurs in which all groups of people will help each other to help each other regardless of their previous social status.

\section{B. Changes in Socio-Economic Conditions}

The socio-economic conditions referred to in this research are the post-disaster social and economic conditions of the community. In this study, this is indicated by the condition of the community after the earthquake on September 282018 in Palu City. The condition of the community is known to have been very badly devastated and hit because of the many damages and even casualties caused by the earthquake. This has an impact on changes in people's lives, including their social conditions. Besides, the damage to infrastructure is also known to have an impact on the economic conditions of the people of Palu.

The impact of the disaster was not only experienced by people in Palu City but also in various countries experiencing disasters. Research in Iran found that physical damage, such as damage to buildings and infrastructure, not only has a direct impact on people's lives but also has the potential to trigger other impacts, such as reduced economic growth and investment, consumption patterns, income sources, and production (Amini Hosseini, Hosseinioon, \& Pooyan, 2013). The same thing also happened in Nepal where the earthquake that occurred had a significant impact on four sectors, namely cross-sectoral (government, environment, employment, social security, and gender), infrastructure, social sector (housing, health, education, and culture), and productive sectors, such as agriculture, industry, tourism, and finance (Shakya, 2016)

Post-disaster social and economic conditions have experienced many changes. The impact of the disasters that occurred in various countries was almost the same as what happened in Indonesia, especially the earthquake in Palu City. This causes the social conditions of society to change, as well as economic conditions. The same impact was also found in the Lombok community after the earthquake.

The results of the research in Lombok found that the socioeconomic conditions of the people of North Lombok Regency have undergone significant changes. Before the earthquake, the socio-economic conditions of the people in Lombok were balanced. This social condition, for example, includes complimentary community and social activities. However, this habit changed drastically after the earthquake, where the community's social life was mostly used to clean and rebuild the rubble of their destroyed houses. Because of this, the time to gather and carry out social activities cannot be done at all. The economic condition in Lombok after the earthquake also experienced a decline, because all economic activities were paralyzed as a result of a significant decline in the economic sector. Before the earthquake, the people of Lombok, like society in general, also carried out economic activities, which included production and consumption, as well as many other economic activities as a source of income (Muttalib, 2019).

Various tragedies that occur related to natural disasters indirectly affect the life of the community in general, which needs special attention to help people survive in disasters. The results of this study are in line with the results of several 
previous studies, namely that natural disasters affects the socio-economic conditions of the people who experience them as a result of infrastructure damage and the number of victims who die. This also indirectly affects the social life and economic conditions of the community. From the social conditions, it can be seen that the large number of victims who died, led to a significant reduction in the population, especially in areas directly affected by the disaster. Damage to infrastructure also indirectly affects the social and economic life of the community. An example is the large number of jobs that were lost due to the damage to infrastructure, which resulted in a decrease in people's income which ultimately disrupted their economic life.

\section{CONCLUSION}

In conclusion, there has been a change in the behavior and socio-economic conditions of the people of Palu City after the earthquake on September 28, 2018 based on the research findings obtained. This behavior change is reflected in the high attitude of mutual help and kinship in the community after the disaster. Even people in Palu city help each other regardless of whether they have family ties or not. Changes also occur in terms of post-disaster socio-economic conditions. The large number of property losses suffered by the people of Palu city due to infrastructure damage has made their social and economic conditions decline. Damage to infrastructure has made jobs disappear and has an impact on the decline in community income after the disaster.

\section{REFERENCES}

[1] Amini Hosseini, K., Hosseinioon, S., \& Pooyan, Z. (2013). An investigation into the socioeconomic aspects of two major earthquakes in Iran. Disasters, 37(3), 516-535.
[2] Dewi, B. V. T., \& Sukmawati, A. M. (2020). Pemetaan Perubahan Kondisi Sosial Ekonomi Masyarakat Pasca Gempa Bumi di Kecamatan Tanjung, Kabupaten Lombok Utara. Jurnal Tata Kota Dan Daerah, 12(2), 83-93.

[3] Hidayati, D. (2008). Kesiapsiagaan Masyarakat: Paradigma Baru Pengelolaan Bencana Alam. Jurnal Kependudukan Indonesia, $3(1), 69-84$.

[4] Mahdia, F., \& Noviyanto, F. (2013). Pemanfaatan Google Maps API untuk pembangunan sistem informasi manajemen bantuan logistik pasca bencana alam berbasis mobile web (studi kasus: Badan penanggulangan bencana daerah Kota Yogyakarta) $(\mathrm{PhD}$ Thesis). Universitas Ahmad Dahlan.

[5] Muttalib, A. (2019). Analisis Dampak Sosial Ekonomi Masyarakat Pasca Bencana Gempa Bumi di Kabupaten Lombok Utara (KLU). Jurnal Ilmiah Mandala Education, 5(2), 84-91.

[6] Pratikno, H., Rahmat, H. K., \& Sumantri, S. H. (2020). IMPLEMENTASI CULTURAL RESOURCE MANAGEMENT DALAM MITIGASI BENCANA PADA CAGAR BUDAYA DI INDONESIA. NUSANTARA: Jurnal Ilmu Pengetahuan Sosial, 7(2), 427-436. https://doi.org/10.31604/jips.v7i2.2020.427-436

[7] Prihatin, R. B. (2018). Masyarakat Sadar Bencana: Pembelajaran dari Karo, Banjarnegara, dan Jepang. Aspirasi: Jurnal MasalahMasalah Sosial, $\quad 9(2), \quad 221-239-239$. https://doi.org/10.46807/aspirasi.v9i2.1106

[8] Rahmat, H. K., \& Alawiyah, D. (2020). Konseling Traumatik: Sebuah Strategi Guna Mereduksi Dampak Psikologis Korban Bencana Alam. Jurnal Mimbar: Media Intelektual Muslim Dan Bimbingan Rohani, 6(1), 34-44.

[9] Shakya, K. (2016). Earthquake: Impact on Nepalese economy and women. Lowland Technology International, 18(2, Sep), 75-82.

[10] Siahaya, J., Siahaya, K. M., \& Rinukti, N. (2020). Tuhan Ada di Mana-mana: Mencari Makna bagi Korban Bencana di Indonesia. KURIOS (Jurnal Teologi Dan Pendidikan Agama Kristen), 6(1), 103-113. https://doi.org/10.30995/kur.v6i1.147

[11] Utomo, M. H., \& Minza, W. M. (2016). Perilaku Menolong Relawan Spontan Bencana Alam. Gadjah Mada Journal of Psychology (GamaJoP), 2(1), 48-59. 